\title{
CRIMINOLOGY CHARACTERISTICS OF CRIMES AGAINST THE PERSON
}

\begin{abstract}
Crimes against life and limb are crimes that constitute a violation of the physical and mental integrity of a person, and are classified as crimes of violence. These criminal acts have been subjected to penalty ever since the first written regulations or codes appeared with the aim to preserve and protect life and body as the most important human and social values. Having in mind the consequences of committing crimes against life and limb, it is clear that the primary task of every state is to work towards their suppression. The precondition for the realization of this task is reflected in the exploration of their criminological characteristics in order to create effective prevention measures through the understanding of the causes of this phenomenon and a comprehensive approach.
\end{abstract}

Keywords: crimes against life and limb, crimes of violence, criminological characteristics.

\section{Introduction}

Although it can be said that all forms of crime have the characteristics of violence in a certain way, in the classification of crime, certain acts are defined as crimes of violence. Violence constitutes the use of physical force that unlawfully endangers the integrity of a person or other goods or values.

Starting from the fact that crimes of violence severely endanger physical integrity, forms of this type of crime can be manifested as homicide and other

\footnotetext{
* PhD Assistant Professor, University Business Academy, Faculty of Law for Commerce and Judiciary, Novi Sad, e-mail: maja.subotin@pravni-fakultet.info

${ }^{* *} \mathrm{PhD}$ Associate Professor, University Business Academy, Faculty of Law for Commerce and Judiciary, Novi Sad, e-mail: jelena@pravni-fakultet.info
} 
acts aimed at depriving a person of life, i.e. murder and attempted murder, injury to bodily integrity and health. ${ }^{1}$

Violence is, in essence, connected with the notion of power, in other words, physical violence is the roughest form of power, where it comes down to the superiority of an individual or group that commits violence and the powerlessness of the victim against whom violence is committed. Thus, although the notion of power is usually associated with material goods and a certain social status, power is also directly related to violence because it can be directed the domination over a person and the life of others. ${ }^{2}$

In that sense, violence essentially implies aggression, specifically intentional and unlawful physical or mental injury to another person or group of people. That is why violent crimes include crimes against life and limb.

\section{Crimes Against Life and Limb in The Criminal Code of The Republic Of Serbia}

Criminal offenses aimed at protecting life and body are located in Chapter Thirteen of the Criminal Code, and this group includes criminal offenses of murder, aggravated murder, manslaughter in a heat of passion, infanticide, mercy killing, negligent homicide, incitement to suicide, and aiding in suicide, illegal termination of pregnancy, serious bodily harm, light bodily injury, brawling, a threat by a dangerous implement in brawl or quarrel, endangerment, abandonment of a helpless person, failure to render aid. ${ }^{3}$

These crimes are systematized first, in the special part of the Criminal Code, and they define life and body as the most important human and social values. Thus, the object of protection from these crimes is defined as a dual set of values: a) life (or the right to life) and b) bodily integrity (physical and mental constitution of a person, i.e. the right to their inviolability). The

\footnotetext{
${ }^{1}$ Bošković, M. (2011). Kriminološka obeležja i tipologija nasilničke ličnosti [Criminological Characteristics and Typology of a Violent Personality] u: Nasilnički kriminalitet - etiologija, fenomenologija, suzbijanje - međunarodno naučno-stručna konferencija [Violent crime - etiology, phenomenology, suppression - international scientific conference]. Banja Luka, Panevropski univerzitet Apeiron, p. 32.

${ }^{2}$ Gajić, G. (2011). Osnovne karakteristike nasilničkog kriminaliteta i njegovih učinilaca [Basic Characteristics of Violent Crime and its Perpetrators] u: Nasilnički kriminalitet - etiologija, fenomenologija, suzbijanje - međunarodno naučno-stručna konferencija [Violent crime - etiology, phenomenology, suppression - international scientific conference]. Banja Luka, Panevropski univerzitet Apeiron, p. 279.

${ }^{3}$ Krivični zakonik [Criminal Code of the Republic of Serbia], Službeni glasnik RS, br. 85/05 ispr., 107/05 - ispr., 72/09, 111/09, 121/12, 104/13, 108/14, 94/16 i 35/19.
} 
act of committing these crimes can be performed exclusively against another person, it cannot be taken against oneself, given that suicide and self-harm are not considered to be crimes. The perpetrator of these crimes can be any person, and when it comes to culpability, these acts can be committed with intent or negligence. The object of protection is the human person, that is, their life. ${ }^{4}$

One of the most serious violent crimes is the crime of murder, and in that sense, it causes special attention to the professional public, but also of the general society, especially when it comes to prevention of this criminal activity. The criminal offense of murder is an incrimination aimed at achieving criminal protection of a person, from the moment of birth to death, and, in that sense, the object of this criminal offense is a living human being. Bearing in mind that the act of committing the criminal offense of murder can be very diverse depending on the manner of commission or the means used, the legislator determined this criminal offense according to the caused consequence, and not according to the modality of execution. ${ }^{5}$

\section{Characteristics of Crimes Against Life and Limb}

The personality of the violent criminal, as a rule, is characterized by aggression, impulsivity, anti-social behaviour, lack of sensitivity, moral principles, lability, paranoia, jealousy, irritability, emotional oscillations, a tendency to other socio-pathological phenomena, etc. ${ }^{6}$ Therefore, a potentially violent criminal can be recognized according to certain characteristics of his personality, which enables him to be provided with adequate help, in a psychological sense, in time, in order to deter him from possibly committing a crime.

According to a survey conducted by the Belgrade Centre for Security Policy on the opinions and attitudes of Serbian citizens when it comes to

\footnotetext{
${ }^{4}$ Jovašević, D. (2017). Krivična dela ubistva [Murder as a Crime]. Beograd, Institut za kriminološka i sociološka istraživanja, pp. 13-15.

${ }^{5}$ Igrački, J. (2015). Krivičnopravne i kriminološke karakteristike nasilničkog kriminaliteta u Srbiji [Criminal and Criminological Characteristics of Violent Crime in Serbia] u: Hughson, M., Stevanović, Z. (editors) Kriminal i društvo Srbije - izazovi društvene dezintegracije, društvene regulacije i očuvanja životne sredine, [Crime and Serbian Society - Challenges of Social Disintegration, Social Regulation and Environmental Protection,]. Beograd, Institut za kriminološka i sociološka istraživanja, p. 79.

${ }^{6}$ Milić, A. (2011). Etiologija i prevencija nasilja [Etiology and Prevention of Violence] u: Nasilnički kriminalitet - etiologija, fenomenologija, suzbijanje - međunarodno naučno-stručna konferencija [Violent crime - etiology, phenomenology, suppression - international scientific conference]. Banja Luka, Panevropski univerzitet Apeiron, p. 70.
} 
violence, as many as $74 \%$ of respondents said they believe that violence in Serbia has increased in recent years. ${ }^{7}$

However, statistical data provided by the Republic Statistical Office show that the number of convicted adults, when it comes to crimes against life and limb, has been decreasing in the last five years. ${ }^{8}$ Despite that, the opinion of the citizens of Serbia speaks in favor of the fact that the general feeling of insecurity among citizens is more pronounced, and the feeling of vulnerability is certainly one of the indicators of the security situation in the country and the need to solve this problem. Especially considering the social and economic impact violent crimes have on society.

Table 1. Convicted adults according to the criminal offense 2015-2019.

\begin{tabular}{|l|c|c|c|c|c|c|c|c|c|c|}
\hline & \multicolumn{2}{|c|}{$\mathbf{2 0 1 5}$} & \multicolumn{2}{c|}{$\mathbf{2 0 1 6}$} & \multicolumn{2}{c|}{2017} & \multicolumn{2}{c|}{$\mathbf{2 0 1 8}$} & \multicolumn{2}{c|}{$\mathbf{2 0 1 9}$} \\
\cline { 2 - 10 } & Number & $\%$ & Number & $\%$ & Number & $\%$ & Number & $\%$ & Number & $\%$ \\
\hline $\begin{array}{l}\text { Crimes } \\
\text { Against Life } \\
\text { and Limb }\end{array}$ & 2074 & 6,2 & 1935 & 5,9 & 1913 & 6 & 1691 & 5,7 & 1403 & 5 \\
\hline
\end{tabular}

Source: Republički zavod za statistiku, Republika Srbija, Podaci - pravosuđe, Osuđena punoletna lica prema krivičnom delu 2015-2019 [Republic Statistical Office, Republic of Serbia, Data - Judicature, Convicted adults according to the criminal offense 2015-2019].

The protection and preservation of the highest human value, human life, represents the individual and general interest of society, which is why the most severe criminal sanctions are envisaged for these types of crimes. This illegal activity of an individual or group that endangers the life and physical integrity of another person can be undertaken in various ways, using different means, or using melee weapons or firearms, dangerous tools, or other means that are suitable to seriously injure or seriously impair human health, as well as the use of physical or mental force or threat.

\footnotetext{
${ }^{7}$ Građani Srbije o nasilju, Istraživanje javnog mnjenja, Građani Srbije o bezbednosti - potencijal za nasilje, Beogradski centar za bezbednosnu politikun [Citizens of Serbia on Security - Potential for Violence]. (2020, September, 04). Available at: http://www.bezbednost.org/upload/document/ gradjani_srbije_o_nasilju_izvestaj.pdf

${ }^{8}$ Punoletni učinioci krivičnih dela u Republici Srbiji - podaci - pravosuđe [Adult Perpetrators of Criminal Offenses in the Republic of Serbia - Data - Judiciary]. (2019). Republički zavod za statistiku, Republika Srbija. (2020, September, 03). Available at: https://www.stat.gov.rs/oblasti/ pravosudje/punoletni-ucinioci-krivicnih-dela/.
} 
Violence is a very specific deviation whose prevalence, changing dynamics, and structure has been significantly influenced by social situations and events in recent years. However, the high prevalence of crimes against life and limb is not the result of transition processes, but their nature is deeply imbued with socio-economic indicators and, as such, they represent one of the main predicaments of modern society. Adequate reaction and treatment of these crimes, and thus violence as a deviant behavior, is essential for the overall success of the transitional reforms and is especially important for Serbia due to the process of joining the European Union. The correlation that exists between all deviant phenomena requires, in addition to the individual, a comprehensive approach in their study. ${ }^{9}$

\section{Etiological Aspect of Crimes Against Life and Limb}

Factors that influence the occurrence of violent crimes, such as crimes against life and limb can be internal, which include psychological and biological factors, and external, in the form of natural and social factors. Although these factors are usually intertwined and related, internal factors contribute to the creation of a tendency towards violence, and external factors often trigger and influence the way violent behavior manifests itself. ${ }^{10}$ Therefore, it is almost impossible to isolate one factor that influences the violent criminal behavior of a person.

Many factors contribute to the growth of violent crime rates, but also crime in general, and these include, above all, social disparities, poverty, corrupt and criminalized government, an inadequate institutional organization in crime prevention, inefficient penal policy, unemployment, structural family anomalies, etc. A survey by the Belgrade Center for Security Policy showed that Serbian citizens see the economic situation, primarily poverty, as the main cause of violence.

The opinion of the respondents who participated in the research of the Belgrade Center for Security Policy on the main causes of violence in Serbia is shown as a percentage in the following table.

\footnotetext{
${ }_{9}^{9}$ Bjelajac, Ž., Matijašević, J. (2013). Nasilje kao oblik socio-patološkog ponašanja [Violence as a Form of Socio-pathological Behavior]. Kultura polisa, 22 (10), p. 423.

${ }^{10}$ Ignjatović, Đ. (2011). Pojam i etiologija nasilničkog kriminaliteta [Definition and Etiology of Violent Crime]. Crimen časopis za krivične nauke, (2), p. 205.
} 
Table 2. Citizens' opinion on the main causes of violence in society expressed as a percentage

\begin{tabular}{|l|c|}
\hline Cause of Violence & Percentage \\
\hline Poor economy, poverty, lack of perspective & $53 \%$ \\
\hline A collapsed societal system of values & $26 \%$ \\
\hline The state is not doing its job & $12 \%$ \\
\hline Subpar educational system & $6 \%$ \\
\hline Does not know & $4 \%$ \\
\hline
\end{tabular}

Source: Građani Srbije o nasilju, Istraživanje javnog mnjenja, Građani Srbije o bezbednosti potencijal za nasilje, Beogradski centar za bezbednosnu politiku, str. 8, [Citizens of Serbia on Violence, Public Opinion Survey Citizens of Serbia on Security - Potential for Violence].

When it comes to the opinion of the respondents regarding the actors responsible for violent crimes, the citizens responded in the manner shown in the next table expressed as a percentage.

Table 3. Stakeholders responsible for violence in society according to the opinion of the citizens of the Republic of Serbia

\begin{tabular}{|l|c|}
\hline Responsible for violence in society & Percentage \\
\hline State/Government & $49 \%$ \\
\hline Only Violent Criminals & $38 \%$ \\
\hline Justice system & $34 \%$ \\
\hline Police & $30 \%$ \\
\hline Political parties & $30 \%$ \\
\hline Individuals who provoke violent criminals & $22 \%$ \\
\hline Parents of Violent Criminals & $20 \%$ \\
\hline The Media & $20 \%$ \\
\hline Education System & $15 \%$ \\
\hline Church and Religious Groups & $10 \%$ \\
\hline Security Information Agency & $4 \%$ \\
\hline
\end{tabular}

Source: Građani Srbije o nasilju, Istraživanje javnog mnjenja Građani Srbije o bezbednosti - potencijal za nasilje, op. cit., p. 10

The fact that almost $50 \%$ of the citizens who participated in the survey consider the state or the Government responsible for violence in society, is extremely alarming, especially having in mind that maintaining security is 
one of the basic roles of the state. Respondents hold the state accountable for violence due to inefficient law enforcement and thus fail to provide adequate protection against violence.

According to many psychologists, pedagogues, criminologists, and other experts, the expansion of crimes against life and limb in recent years has been significantly influenced by the mass media, especially when it comes to minors. Bearing in mind that young people are prone to easily identify with negative personalities, that violence in certain situations incites other violence, that criminal techniques are often learned through the media and imitated $n$ real-world criminal behavioral patterns, it is clear that it is necessary to direct media goals towards strategies that promote responsible behavior. Not only by limiting antisocial behavior in the media but also towards limiting content that encourages violent behavior and moral degeneration. ${ }^{11}$

Such action is especially important given that the media is in third place as sources of learning and adopting violent behavior, while the first two are occupied by the family and social environment. By watching media violence, children become more tolerant of violence, develop wrong attitudes, experience the world as a violent place where the fear of violence is constantly present. In that climate and the feeling of compassion for the victims of violence disappears. As a result of these consequences, antisocial and violent behavior occurs, so it can be concluded that the power and responsibility of the media, in the context of influencing children, but also society as a whole, is extremely high. ${ }^{12}$

\section{Prevention measures}

Measures to combat and prevent violence, specifically crimes against life and limb, can be repressive and preventive, and in terms of specific measures that the state should take to reduce violence in society, citizens who participated in the research of the Belgrade Centre for Security Policy responded as shown in the following table.

\footnotetext{
${ }^{11}$ Skakavac, Z., Skakavac, T. (2011). Uticaj medija na ekspanziju nasilničkog kriminaliteta [The Influence of the Media on the Expansion of Violent Crime] u: Nasilnički kriminalitet - etiologija, fenomenologija, suzbijanje - međunarodno naučno-stručna konferencija [Violent Crime - Etiology, Phenomenology, Suppression - International Scientific Conference]. Banja Luka, Panevropski univerzitet Apeiron, p. 216.

${ }^{12}$ Torlak, N. (2016). Slika maloletnika u medijima - deca kao posmatrači nasilja [Figure of Juveniles in The Media - Children as Victims and Observers of Violence], Komunikacije, mediji, kultura, (8), pp. 222-223.
} 
Table 4. Measures that the state should implement in order to reduce violence in society according to the opinion of the citizens of Serbia

\begin{tabular}{|l|c|}
\hline $\begin{array}{l}\text { What is the most important measure that the state should } \\
\text { implement to reduce violence in society? }\end{array}$ & Percentage \\
\hline To arrest and punish more. & $34 \%$ \\
\hline To improve the country's economy. & $28 \%$ \\
\hline To invest more in preventing violence through youth education. & $26 \%$ \\
\hline To ban extremist groups. & $6 \%$ \\
\hline Don't know & $4 \%$ \\
\hline
\end{tabular}

Source: Građani Srbije o nasilju, Istraživanje javnog mnjenja, Građani Srbije o bezbednosti - potencijal za nasilje, op. cit., p. 20.

From the results of the research, we can conclude that the citizens of Serbia believe that primarily repressive measures can reduce the occurrence of violence in society. However, precisely because, according to the opinion of most citizens, the economic situation is less than ideal, widespread poverty, high unemployment rate, etc. the primary cause of crime in general, and especially when it comes to crimes against life and limb, we can summarize that the most effective preventive measure would be to improve the economic situation in the country combined with youth education and other preventive measures.

Given that repressive measures cannot be sufficient to combat crimes against life and limb, it is necessary to develop a wide range of preventive measures such as eliminating the causes of violent crimes, through education and non-sensational spread of information about violence, raising the level of education and training of all stakeholders who can, through the performance of their profession, recognize a potential perpetrator and contribute to the suppression of addiction diseases, which are often directly related to violent behavior.

In terms of prevention of most crimes against life and limb, the location of criminal activity is also of key importance, numerous studies show that reducing noise and pollution, as well as overcrowding in large cities can contribute to combating this phenomenon. Thus, increased measures of maintaining communal order and planned urban development may be reflected in the reduced rate of violent crimes. ${ }^{13}$

\footnotetext{
${ }^{13}$ Ignjatović, Đ. (2011). Nasilnički kriminalitet - konceptualna i etiološka pitanja [Violent Crime - Conceptual and Etiological Questions] u: Nasilnički kriminalitet - etiologija, fenomenologija, suzbijanje - međunarodno naučno-stručna konferencija [Violent Crime - Etiology, Phenomenology, Suppression - International Scientific Conference]. Banja Luka, Panevropski univerzitet Apeiron, p. 26.
} 
The necessity of considering, improving, and implementing all forms of measures to suppress violent crime is imposed as an imperative because apart from the fact that violence directly endangers people's lives, and thus the security of the state, the consequences of violence are felt in social, psychological and economic terms.

The fact that more than one million and six thousand people lose their lives due to violence every year speaks volumes about the impact that violent crime has on security on a global level. However, even more, people feel the consequences of violence in the form of psychological, sexual, reproductive, and mental problems. ${ }^{14}$

Violent crimes have consequences for the state in both economic and social spheres. Violence leads to a reduction in human resources, lower labor market participation rates, reduced productivity at work and longer absences, as well as lower incomes, reduced future productivity of children growing up in a violent environment, and macroeconomically it contributes to reduced investment and savings. When it comes to social consequences, one of the manifestations of violent crime consequences is an intergenerational transmission of violence, reduced participation in democratic processes, poorer quality of life, and other direct or indirect social problems. ${ }^{15}$

\section{Conclusion}

Crimes against life and limb are focused on incrimination whose goal is the protection of life and body as the most important human and social value, which is why they are systematized first in the special part of the Criminal Code of the Republic of Serbia. Since they involve intentional and unlawful physical and mental injury to another person or group of people, they are classified as violent crimes.

Statistics show that the number of these crimes has been steadily declining in recent years, however, this certainly does not mean that it is not necessary to work more decisively on their suppression, bearing in mind that the crime rates, although, declining are still high. Of particular concern is the fact that the citizens of Serbia believe that violent crime is on the rise in recent years, which speaks in favor of the fact that the collective sense of security at am all-time low.

By identifying the factors that influence the occurrence of violent behavior and analyzing the personality of criminals, academia can contribute to the

\footnotetext{
${ }^{14}$ World Health Organization, World raport on violence and health (2020 September 05), Available at: http://www.who.int/violence_injury_prevention/violence/world_report/en/summary_en.pdf?ua=1 ${ }^{15}$ Buvinic M., Morrison, A. (1999). Violence as an Obstacle to Development, 1-8, Washington, DC, Inter-American Development Bank, pp. 4-5.
} 
creation of more effective prevention measures and thus reduce the number of violent offenses. Among the factors that affect the occurrence of crimes against life and limb are poverty, social differences, corruption, ineffective penal policy, structural anomalies in the family, the influence of the media, the mental health of the population, and others. Research has shown that the majority of Serbian citizens believe that the main cause of violence and crimes against life and limb, is the poor economy.

Given the seriousness and scale of this problem, the primary task of each government is to suppress the occurrence of crimes against life and limb to the lowest possible rate through its internal regulations, strategies, preventive and repressive measures, as well as its impact on the causes of violent behavior. Thus, improving security and the quality of life of all citizens.

\section{Subotin Maja}

Dr, Docent, Pravni fakultet za privredu i pravosuđe u Novom Sadu, Univerzitet Privredna akademija u Novom Sadu

\section{Matijašević Obradović Jelena}

Dr, Vanredni profesor, Pravni fakultet za privredu i pravosuđe u Novom Sadu, Univerzitet Privredna akademija u Novom Sadu

\section{KRIMINOLOŠKA OBELEŽJA KRIVIČNIH DELA PROTIV ŽIVOTA I TELA}

REZIME: Krivična dela protiv života i tela predstavljaju krivična dela kojima se povređuje ili ugrožava život, odnosno fizički ili psihički integritet čoveka i svrstavaju se u delikte nasilja. Ova krivična dela za cilj imaju očuvanje i zaštitu života i tela kao najznačajnije ljudske i društvene vrednosti. Imajući u vidu posledice izvršenja krivičnih dela protiv života i tela, jasno je da primarni zadatak svake države predstavlja njihovo suzbijanje. Preduslov za realizovanje ovog zadatka ogleda se u sagledavanju njihovog kriminološkog aspekta kako bi se kroz razumevanje uzroka ove pojave i kroz sveobuhvatan pristup kreirale efikasne mere prevencije.

Ključne reči: krivična dela protiv života i tela, delikti nasilja, kriminološka obeležja. 


\section{References}

1. Bjelajac, Ž., Matijašević, J. (2013). Nasilje kao oblik socio-patološkog ponašanja [Violence as a Form of Socio-pathological Behavior]. Kultura polisa, 22 (10), pp. 409-425

2. Bošković, M. (2011). Kriminološka obeležja i tipologija nasilničke ličnosti [Criminological Characteristics and Typology of a Violent Personality] u: Nasilnički kriminalitet - etiologija, fenomenologija, suzbijanje - međunarodno naučno-stručna konferencija [Violent crime - etiology, phenomenology, suppression - international scientific conference]. Banja Luka, Panevropski univerzitet Apeiron, pp. 32-49

3. Buvinic M., Morrison, A. (1999). Violence as an Obstacle to Development, 1-8, Washington, DC, Inter-American Development Bank

4. Gajić, G. (2011). Osnovne karakteristike nasilničkog kriminaliteta i njegovih učinilaca [Basic Characteristics of Violent Crime and its Perpetrators] u: Nasilnički kriminalitet - etiologija, fenomenologija, suzbijanje - međunarodno naučno-stručna konferencija [Violent Crime - Etiology, Phenomenology, Suppression - International Scientific Conference]. Banja Luka, Panevropski univerzitet Apeiron, pp. 278-296

5. Građani Srbije o nasilju, Istraživanje javnog mnjenja, Građani Srbije o bezbednosti - potencijal za nasilje, [Citizens of Serbia on Security - Potential for Violence]. Beogradski centar za bezbednosnu politiku, Available at: http://www.bezbednost.org/upload/document/gradjani_srbije_o_nasilju izvestaj.pdf

6. Ignjatović, Đ. (2011). Nasilnički kriminalitet - konceptualna i etiološka pitanja [Violent Crime - Conceptual and Etiological Questions] u: Nasilnički kriminalitet - etiologija, fenomenologija, suzbijanje - međunarodno naučno-stručna konferencija [Violent Crime - Etiology, Phenomenology, Suppression - International Scientific Conference]. Banja Luka, Panevropski univerzitet Apeiron, pp. 5-31

7. Ignjatović, Đ. (2011). Pojam i etiologija nasilničkog kriminaliteta [Definition and Etiology of Violent Crime]. Crimen časopis za krivične nauke, (2), pp. 179-211

8. Igrački, J. (2015). Krivičnopravne i kriminološke karakteristike nasilničkog kriminaliteta u Srbiji [Criminal and Criminological Characteristics of Violent Crime in Serbia] u: Hughson, M., Stevanović, Z. (editors.), Kriminal i društvo Srbije: izazovi društvene dezintegracije, društvene regulacije i očuvanja životne sredine, [Crime and Serbian Society: Challenges of Social Disintegration, Social Regulation and Environmental 
Protection,]. Beograd, Institut za kriminološka i sociološka istraživanja, pp. 79-98.

9. Jovašević, D. (2017). Krivična dela ubistva, [Murder as a Crime]. Beograd, Institut za kriminološka i sociološka istraživanja

10. Krivični zakonik [Criminal Code of the Republic of Serbia], Službeni glasnik $R S$, br. 85/05 - ispr., 107/05 - ispr., 72/09, 111/09, 121/12, 104/13, 108/14, 94/16 i 35/19

11. Milić, A. (2011). Etiologija i prevencija nasilja [Etiology and Prevention of Violence] u: Nasilnički kriminalitet - etiologija, fenomenologija, suzbijanje - međunarodno naučno-stručna konferencija, [Violent crime - etiology, phenomenology, suppression - international scientific conference]. Banja Luka, Panevropski univerzitet Apeiron, pp. 65-74

12. Punoletni učinioci krivičnih dela u Republici Srbiji - podaci - pravosuđe [Adult Perpetrators of Criminal Offenses in the Republic of Serbia - Data - Judiciary]. (2019). Republički zavod za statistiku, Republika Srbija, Available at: https://www.stat.gov.rs/oblasti/pravosudje/punoletniucinioci-krivicnih-dela/

13. Skakavac, Z., Skakavac, T. (2011). Uticaj medija na ekspanziju nasilničkog kriminaliteta [The Influence of the Media on the Expansion of Violent Crime] u: Nasilnički kriminalitet - etiologija, fenomenologija, suzbijanje - međunarodno naučno-stručna konferencija [Violent Crime - Etiology, Phenomenology, Suppression - International Scientific Conference]. Banja Luka, Panevropski univerzitet Apeiron, pp. 204-217

14. Torlak, N. (2016). Slika maloletnika u medijima - deca kao posmatrači nasilja [Figure of Juveniles in The Media - Children as Victims and Observers of Violence]. Komunikacije, mediji, kultura, (8), pp. 213-224

15. World Health Organization, World Report on Violence and Health, Available at: http://www.who.int/violence_injury_prevention/violence/ world_report/en/summary_en.pdf?ua $=1$ 